\title{
Kaum Syiah di Indonesia: Perjuangan Melawan Stigma
}

\author{
Zulfan Taufik \\ Dosen STAI Nur El-Ghazy Bekasi
}

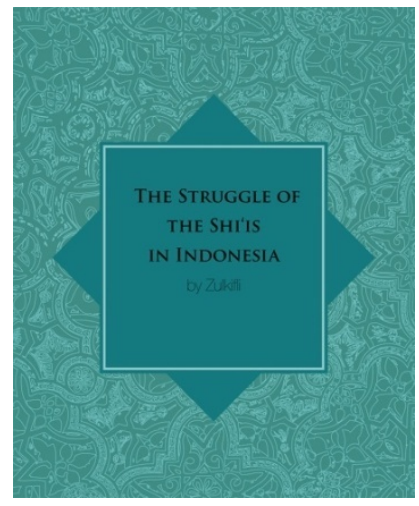

\begin{tabular}{|c|c|}
\hline Penulis & Zulkifli \\
\hline Judul & $\begin{array}{l}: \text { The Struggle of the Shi' is } \\
\text { in Indonesia }\end{array}$ \\
\hline Penerbit & $\begin{array}{l}\text { : Australian National } \\
\text { University Press }\end{array}$ \\
\hline Tahun & 2013 \\
\hline Jumlah Halaman & xxiv +304 \\
\hline ISBN & $\begin{array}{l}9781925021295 \text { (paper) } \\
9781925021301 \text { (ebook) }\end{array}$ \\
\hline
\end{tabular}

Sementara Sunnisme yang mendominasi di Indonesia telah banyak diteliti oleh para ahli dengan menggunakan berbagai pendekatan, realitas Syiisme dalam dimensi historis, sosiologis, politis, dan religiusnya di Indonesia hampir tidak dikenal di kalangan sarjana atau bahkan di antara mayoritas Muslim sendiri. Padahal, pemahaman tentang kelompok Syiah sangat penting untuk pemahaman kita tentang agama dan masyarakat Indonesia pada umumnya. Kehadiran Syiisme di Indonesia sebagai sebuah wacana intelektual, baru menemukan momentumnya beberapa tahun setelah Revolusi Islam Iran pada tahun 1979. Pada awal dekade 1980-an, mulai bermunculan berbagai buku karya para pemikir dan tokoh Islam Syiah Iran seperti Allamah Thabathaba'i, Murtadha Muthahhari, dan Ali Syariati. Sejak saat itu, berbagai kajian, penelitian, dan seminar yang berkaitan dengan Shi' isme mulai marak dikaji dan ditelaah secara lebih mendalam.

Buku yang merupakan hasil penelitian doktoral Zulkifli di Universitas Leiden ini, mencoba untuk mengatasi ketimpangan tersebut dan untuk memahami realitas Syiah di Indonesia secara komprehensif. Meskipun telah ada beberapa penelitian sebelumnya yang relevan mengenai Syiah di Indonesia, aspek-aspek utama dari kehidupan sosial dan keagamaan dari kelompok Muslim yang minoritas ini, termasuk pembentukan denominasi 
kelompok Syiah, pemimpin-pemimpin utamanya, kepercayaan dan prakteknya, dakwah, pendidikan, penerbitan dan organisasi serta reaksi dari mayoritas kelompok Sunni belum sepenuhnya terungkap.

Sepanjang kajian di dalam buku ini, penulis hampir tidak pernah menggunakan istilah 'Shi'a'. Pun bila digunakan, istilah tersebut mengacu kepada makna generik, 'partition'. Penulis umumnya menggunakan istilah Shi 'ism untuk menunjukkan denominasi yang bertentangan dengan Sunnism. Sedangkan kata Shi'i digunakan untuk kata sifat dan juga kata benda orang (human noun). Selain itu, Zulkifli membatasi makna Shi ism pada bentuk Syiha Ithna 'Ashariyyah (juga dikenal sebagai Syiah Dua Belas Imam atau Ja'fari), yakni mazhab yang memuliakan dua belas Imam yang menggantikan Nabi Muhammad dan telah mengadopsi serangkaian praktek tertentu sebagai konsekuensi dari sistem keyakinannya.

Dalam menganalisis kelompok Syiah di Indonesia sebagai kelompok Muslim minoritas, penulis menggunakan teori 'stigma' yang diusung oleh sosiolog Erving Goffman. Menurut teori Goffman, kelompok yang terstigma cenderung untuk mengadopsi strategi yang masuk ke dalam sistem sosial yang didominasi oleh mayoritas. Dalam konteks tersebut, Sunnisme telah menjadi norma di dunia Muslim, sementara Shi'isme dianggap 'abnormal' sehingga kelompok Syiah harus menerapkan strategi tertentu untuk mendapatkan pengakuan dan rasa hormat dari mayoritas Sunni. Penulis juga mengikuti langkah Devin Stewart dalam studinya tentang "Respon Syiah Imamiyah terhadap Teori Hukum Sunni" (Twelver Shi'i Response to Sunni Legal Theory). Stewart menerapkan teori ini untuk Syiah "yang telah hidup sebagai kelompok minoritas yang terstigma dan didominasi oleh mayoritas yang berpotensi untuk bermusuhan di sebagian besar wilayah dunia Muslim dan selama sebagian besar periode sejarah Islam."

Buku ini didasarkan pada penelitian lapangan dan penelitian kepustakaan. Penulis melakukan dua periode kerja lapangan di beberapa kota di Indonesia seperti Jakarta dan Bandung. Setiap periode berlangsung selama delapan bulan. Pertama mulai dari Juni 2002 hingga Januari 2003, dan yang kedua dimulai dari Oktober 2003 hingga Mei 2004. Ia mewawancarai tokohtokoh Syiah serta pengikutnya, mengamati dan berpartisipasi dalam sejumlah kegiatan keagamaan di lembaga Syiah, mengunjungi perpustakaan mereka, berdialog, mengumpulkan buku-buku Syiah dan anti-Syiah, majalah, pamflet, kaset, DVD, dan juga mengumpulkan informasi dari situs-situs organisasi dan lembaga. Untuk memfasilitasi interaksinya dengan anggota Syiah, penulis 
mengambil kursus bahasa Persia selama tiga bulan di Islamic Cultural Center (ICC) Jakarta selama Januari-Maret 2004. Guna mengumpulkan data tentang tanggapan Sunni, Zulkifli mengunjungi kantor DDII (Dewan Dakwah Islamiyah Indonesia), LPPI (Lembaga Pengkajian Dan Penelitian Islam) di Jakarta, pusat Persis (Persatuan Islam) di Bandung dan Bangil, perpustakaan MUI (Majelis Ulama Indonesia) di Masjid Istiqlal Jakarta, Badan Penelitian dan Pengembangan Departemen Agama Jakarta, UIN Syarif Hidayatullah Jakarta, dan UIN Sunan Gunung Djati Bandung.

Peneliti menyajikan pembahasan dalam buku ini ke dalam sembilan bab, di samping pendahuluan. Bab Satu menggambarkan unsur dan faktor utama dalam pembentukan sejarah komunitas Syiah di Indonesia. Hal ini diikuti Bab Dua dengan penjelasan tentang jenis-jenis pemimpin dalam komunitas Syiah dan potret Husein al-Habsyi, Husein Shahab, dan Jalaluddin Rakhmat. Bab Tiga meneliti karakteristik Syiah sebagai mazhab seperti yang dipahami dan dipraktekkan oleh kelompk Syiah di Indonesia. Hal ini termasuk menguraikan konsep ahl al-bayt, doktrin Imamah dan Mahdi, Ja'fari yurisprudensi, aspek kesalehan Syiah, serta pengajaran dan praktek taqiyya. Bab Empat, Lima, dan Enam menjabarkan tentang upaya kelompok Syiah untuk menyebarkan ajaran mereka di masyarakat Indonesia dan untuk mendapatkan pengakuan sebagai interpretasi yang valid dari Islam. Bab-bab ini meneliti lembaga yang didirikan oleh Syiah dan termasuk analisis bidang dakwah, pendidikan dan penerbitan. Dalam bab tentang dakwah, penulis menggambarkan karakteristik lembaga Syiah dan cara-cara dakwah yang telah dilakukan, termasuk menyatakan cita-cita, jenis kegiatan dakwah, dan pelatihan dakwah. Bab tentang pendidikan menyuguhkan laporan dari lembaga pendidikan yang diselenggarakan oleh tokoh-tokoh Syiah terkemuka. Sarana lain yang penting dalam penyebaran Syiisme adalah melalui bidang penerbitan yang dibahas dalam Bab Enam, dengan survei tentang penerbit kelompok Syiah dan produk mereka, serta dampak publikasi tersebut.

Bab Tujuh mendalami IJABI (Ikatan Jamaah Ahlul Bait Indonesia), organisasi massa yang dibentuk oleh kelompok Syiah sebagai sarana untuk mendapatkan pengakuan hukum dari otoritas negara. Tentang catatan sejarah pendiriannya, fondasi ideologis dan perkembangannya disajikan secara rinci dalam bab ini. Akhirnya, sebuah kajian tentang Syiisme di Indonesia tidak akan pernah lengkap tanpa mengungkap tanggapan beragam dari mayoritas Muslim Sunni. Oleh karena itu Bab Delapan mencakup analisis sikap umum organisasi Sunni yang besar, baik tradisionalis maupun reformis terhadap 
Syiisme dan tanggapan Majelis Ulama Indonesia (MUI) serta Departemen Agama. Bab ini juga menyajikan deskripsi tentang cara kelompok-kelompok anti-Syiah menyebarkan propaganda melawan Syiah. Hal ini diikuti oleh penjelasan sikap moderat intelektual Muslim berpengaruh, yang telah membuka jalan untuk pengembangan lebih lanjut Syiah di Indonesia. Sebagai penutup, disusunlah Bab Sembilan yang menyajikan kesimpulan kajian ini.

Data dan analisis dalam buku ini menunjukkan realitas beragam (multifaceted) yang dihadapi oleh kelompok Syiah yang hidup di tengah-tengah mayoritas Sunni di Indonesia. Sebagai kelompok yang terstigma, Syiah menerapkan beragam strategi tergantung pada situasi politik, sosial, dan religius yang ada untuk menduduki kekuasaan yang sah dalam masyarakat. Sepanjang sejarah mereka, kelompok Syiah berjuang untuk mendapat pengakuan yang, bagi mereka, merupakan dimensi fundamental dalam kehidupan sosial, dan merupakan tugas tanpa akhir.

Namun sayangnya, secara teoritis kajian ini tidak menghasilkan sebuah teori baru yang signifikan, karena masih terpaku pada teori 'stigma' dari Erving Goffman yang ia gunakan. Bahwa sebuah kelompok yang terstigma akan menggunakan beragam strategi yang sesuai dengan konteks mayoritas guna mendapat pengakuan dan rasa hormat. Persis seperti itulah yang penulis buktikan dalam kajiannya tentang perjuangan kelompok Syiah di Indonesia untuk melawan stigma dari mayoritas kelompok Sunni. Selain itu, makna Syiisme hanya terbatas pada bentuk Syiah Ithna 'Ashariyyah yang telah menafikan bentuk Syiah lainnya seperti Zaidiyyah dan Isma'iliyyah. Meskipun komunitas mereka relatif sangat kecil dibandingkan dengan Syiah Ithna 'Ashariyyah, mereka juga eksis dalam realitas masyarakat Indonesia. Kajian ini juga tidak memberikan tipologi pengikut Syiah di Indonesia, meskipun pada Bab Dua dijelaskan formasi komunitas Syiah di Indonesia. Padahal hal ini penting untuk mendapatkan pemahaman yang lebih mendalam mengenai identitas riil dan angka pasti terkait jumlah pengikut Syiah di Indonesia.

Terlepas dari beberapa kelemahannya, sebagai sebuah hasil kajian akademik yang telah melalui berbagai proses 'uji', revisi, dan suntingan, buku ini sangat penting dibaca, baik oleh pembaca umum maupun para peneliti yang tertarik terhadap kajian Syiah dan keindonesiaan. Kajian ini berhasil sebagai starting point untuk memahami Syiah di Indonesia sekaligus landasan bagi kajian lanjutan. Sebagaimana komentar James Fox dalam pengantar buku ini, bahwa karya Zulkifli ini merupakan kajian kesarjanaan dalam bahasa 
Inggris pertama yang membahas secara komprehensif tentang perkembangan Syiah di Indonesia. Buku ini juga penting dijadikan rujukan acuan bagi pemerintah pembuat kebijakan, demi mendapatkan pemahaman yang baik dan komprehensif mengenai realitas kelompok Syiah di Indonesia dan usahausaha yang mereka lakukan untuk melawan stigma yang 'terlanjur' dilekatkan kepada mereka. 